\title{
CAUSAL UNCERTAINTY AND TRANSLATION
}

\author{
Daša MUNKOVÁ, Soňa HODÁKOVÁ, Katarína WELNITZOVÁ \\ Constantine the Philosopher University in Nitra \\ Štefánikova 67, 94974 Nitra, Slovak Republic \\ E-mail: \{dmunkova, shodakova,kwelnitzova\}@ukf.sk
}

\begin{abstract}
This study is aimed at causal uncertainty (CU) as a personal self-construct in a social environment and its influence on the translation process, focusing on the relationship between an individual causal uncertainty and selected indicators of translation or interpreting (free/literal translation, adequacy/inadequacy translation, language fluency of translation and the quality of interpreting into the mother tongue). For this purpose the CUS scale was used and regression analysis was applied. The results showed a statistically significant influence of causal uncertainty of an individual on a willingness to apply for internship abroad and on a tendency to literal/free translation.
\end{abstract}

Key words: causal uncertainty $(\mathrm{CU})$, translation process, indicators of translation and interpreting, internship

\section{INTRODUCTION}

Within the last few decades, an interdisciplinary approach to translation studies has been focused on the study of the relationship between psychological characteristics and the quality of translation and interpreting (Kurz, 1994, 2002; Pöchhacker, 1999; Hodáková, 2009, and others). In most cases, cognitive skills influencing the process of translation have been discussed. Although, following the existing studies, research on the personal and interpersonal features of a translator seems to be lacking. Thus, this study discusses causal uncertainty as a personal self-construct in a social environment and its influence on the translation process.

For this reason, research has been carried out in which 42 students of Translation Studies took part. We examined the relationship between causal uncertainty and certain se- lected indicators of translation (Translation - literal/free, Translation - adequate/inadequate, Fluency, Translation Quality into Mother Tongue) and also between causal uncertainty and certain variables (Academic Achievements, Internships and Study Year). We attempted to discover the extent to which selected indicators explain or affect causal uncertainty of an individual.

\section{CAUSAL UNCERTAINTY ANDTRANSLATION PROCESS}

The concept of causal uncertainty (CU) is highly related to the personal need for structure (PNS). Neuberg and Newsom (1993) identified two conceptually significant aspects of the need for structure. One of them is related to the extent of a desired structure in everyday life (desire for structure). Individuals with a high desire for structure prefer a clear and structured way of life and strict structure schemes. The

DOI: $10.21909 / \mathrm{sp} .2014 .03 .662$ 
second aspect of a need for structure is represented by the response to lack of structure, which clearly shows how individuals cope with unstructured and unpredictable situations. People who show a significant dislike for uncertain situations or sudden change of plans score highly in the response to lack of structure. The results of the studies indicate that the factors of the PNS Scale (Personal Need for Structure) have a different relationship with personal features: response to lack of structure (RLS subscale) is related to neuroticism and introversion; conversely, desire for structure (subscale DFS) is not. Sarmány-Schuller (2001) has similarly discovered that anxiety examined by the SPSR - R scale (devised by Torrubiu et al., in Sarmány-Schuller, 2001) is significantly different in personal need for structure in the RLS factor - response to lack of structure, however, not in the DFS factor-desire for structure.

The theory of Weary and Edwards (1994) is based on the assumption that most people feel uncertain in their cause-and-effect understanding of the world. Moreover, there exist some chronic individual differences in the uncertainty beliefs of people and in their ability to identify and understand causal relationships in the social world. Causal uncertainty is likely to influence people's thinking and behavior. The impact is significant and can be shown in information searching and processing, since the given activities are highly related to understanding of causality. Expectation and uncontrollability are highly related to causal uncertainty, both chronic and situational. Empirical studies examining certainty and uncertainty (e.g., Sarmány-Schuller, 1999) provided the evidence that uncertainty represents the phenomenon associated with the ability to categorize and structure information about the world. A high ability to achieve the structure helps the individual to gain certainty and it is connected with lower stress or more effective coping.

From studying certainty and uncertainty beliefs, several concepts pointing at the different explanations of the prevailing forms of people's behavior have been devised. Tolerance of ambiguity or uncertainty (Frenkel-Brunswick, 1948) expresses people's ability to perceive and process information about uncertain stimuli (or the stimuli which they consider ambiguous). Individuals with a low tolerance of ambiguity or uncertainty consider such situations as stressful, their reactions are immature and they tend to avoid them (Sarmány-Schuller, 2001). Conversely, people with a high tolerance of ambiguity and uncertainty perceive such situations or stimuli as desirable, challenging and interesting; basically they do not tend to avoid them, their complexity is not disrupted by incongruence.

The research (Weary et al., 2010) shares the notion that high causal uncertainty is related to depression, neuroticism, social anxiety, shyness and loneliness. It also influences interpersonal relationships. Individuals with low causal uncertainty are able to have social interactions without the need to analyze them. Individuals high in causal uncertainty are likely to have difficulties in social relationships. Inability to comprehend or identify causal relationships or causal conditions can materialize into feelings of disorientation, discomfort, or turmoil. The factors causing $\mathrm{CU}$ are: surroundings, individual expectations, and self-perception. The studies have shown that moderately depressed individuals are more sensitive to the information which can reasonably ren- 
der their worlds more understandable, predictable and controllable. This need is given by the attribute-by-attribute processing of social information (Weary et al., 2010). One of the postulates of the $\mathrm{CU}$ model is that $\mathrm{CU}$ activates accuracy motivation. People who are accuracy motivated will exhibit increased effort when processing information, presumably because they believe that such effort will lead to greater accuracy (Edwards, 2003). Further, Weary et al. (2006) found that high $\mathrm{CU}$ was associated with increased correction of dispositional attribution. However, the results held true only when high CU individuals were not under cognitive load. These results suggest that effortful cognitive operations were driving the corrections. The specific problem or the "challenge" that interpreters and translators in the process of translation need to cope with is that of effort managing, including cognitive efforts managing. Based on the mental processes during interpreting, Gile (1993, 1995) devised a modéle d'efforts. In the process of interpreting, he distinguishes several capacity demands/efforts - reception, memory and production of the target text. In the process of translating, we are pointing particularly at the high cognitive load.

There has been no study focusing on the relationship between $\mathrm{CU}$ and selected aspects of interlingual or intercultural communication. Some studies have focused on the relationship between uncertainty reduction and verbal communication in which spontaneous speech was discussed (Sherblom, van Rheenen, 1984; Berger, Bradac, 1982), but not mediated communication.

This study focuses on the relationships between causal uncertainty of the individual and selected aspects of translation or inter- preting. Both represent intercultural and interlingual transfers with distinctive specifics in each form. Translation is defined by the following characteristics: written form, durability, unlimited number of recipients, different temporal and local conditions of source and target text, no feedback, possibility of rectification, concurrent preparation for translation, complexity of transfer, sufficient context (the complete source text is available, anticipation strategies are not needed), flexible and quick thinking as a secondary demand, relatively stable working conditions (see Müglová, 2009).

Regarding particular aspects of the quality of translation, the study describes the following indicators:

- free/literal translation of the selected text segments

- adequacy/inadequacy of the selected text segments

- overall evaluation of the language fluency.

Adequacy of translation represents a pragmatic category; the relationship between expressive unique features and the aims of communication. By adequate translation we mean translation in which the appropriate features have been used to express the intention of the author in the target language (Müglová, 2009).

When evaluating the category free/literal translation, we consider the concept of the American translation theorist Nida (see Nida, Taber, 1969). He distinguishes formal and dynamic equivalence. Formal equivalence is identical to the literal translation, the latter represents a free and at the same time functionally consistent translation.

The category of language fluency is related to the overall evaluation of translation from the view point of a reader who is not 
familiar with the source text. Fluency of language is determined by comprehension, cohesion, coherence and by the translator's ability to preserve the rules within the macrostructure and microstructure of the target language.

In addition, this study is focused on the relationship between causal uncertainty and the quality of interpreting. Within the opposition of translation - interpreting the basic striking features of interpreting can be defined as follows: oral form, temporary reception, limited number of recipients/listeners, usually identical temporal and local conditions of the source and target text, dependence on the speaker's speech rate, partial feedback, low or zero opportunity of translation rectification/selfcorrection, transfer reduction, low or zero context (the interpreter's anticipation strategy is highly needed), the need for synchronization of understanding and re-expressing, the need for effective cognitive management, the need to engage working memory functions, the need to cope with stress, flexible and quick thinking as a primary demand on the interpreter, rhetorical preconditions needed and dynamic working conditions (Müglová, 2009).

By the quality of the interpreter's performance we understand the adequacy of the target text considering both the form and content (information value, the author's intention, fluency of speech, grammar correctness, or use of terminology).

As mentioned above, translation and interpreting represent interlingual and intercultural activities. The intercultural competence of the translator and interpreter is viewed as a significant skill (Gromová, Janecová, 2013; Stefč́́k, 2012; Ďuračková, Čechová, 2012); one of the extremely important characteris- tics of the mediator, as it helps him/her to understand the cultural habits, traditions and beliefs of society. Moreover, intercultural differences (differences in verbal and nonverbal features) may play a key role in understanding and further transferring the source text meaning. It seems obvious that the most efficient way to develop intercultural competence is internship abroad (mobility). One part of this research has focused on the relationship between causal uncertainty and the willingness of the students to apply for internship.

Based on the studies of Weary and her colleagues (Weary, Edwards, 1994; Weary et al., 2010) focusing also on the relationships between causal uncertainty and GPA (gradepoint average), we also included GPA ( $a c a$ demic achievements) of students into the research.

\section{METHOD}

\section{Participants}

The subjects were students of Translation Studies at Constantine the Philosopher University in Nitra. The final sample of 42 people (32 women and 10 men) were students in the 3 rd year of the bachelor's study program and the 1st and 2nd year of the master's study program - Translation Studies. The average age of students was 22.1 years. Total scores in CUS ranged from 15 to 56, the mean score in the group was 36.14 . The subjects were also split into groups according to their foreign-language competence ranging from 1 (below-average) to 3 (above-average), the mean was 1.69. The students were divided into groups according to their results in linguistic subjects within the bachelor's study program. 


\section{Measures and Procedure}

Within the evaluation of the translated text and selected translation procedures, we targeted the following indicators (variables):

- F1: free/literal translation of selected text segments (scale 1-3), with the mean of 1.56

- F2: adequate /inadequate translation of selected text segments (scale 1-3), with the mean of 1.85

Overall evaluation of the target text (fluency, F3) was conducted by 5 observers recipients who were not familiar with the source text. All subjects were asked to translate the same text and the final evaluation was represented by the average score of all observers, the scale ranged from 1 to 5 , with the mean of 3.00.

The interpreter's performance (interpreting into their mother tongue, F4) was conducted by 5 observers. Each of them evaluated the quality of 4 interpreted speeches (texts), comparing the source and target text. The subjects interpreted the same texts in the booths and their speeches were recorded. The final evaluation was represented by the average score of all observers. The scale ranged from 1 to 3 , the mean score was 1.61.

Concerning the subjects' university studies of translation and interpreting, we focused on their GPA (Academic Achievement, F5) and participation in the long-term internships (F6). The GPA values ranged from 1.09 to 2.03 , the mean score was 1.53 .

Causal uncertainty was measured with the Causal Uncertainty Scale (CUS, Weary, Edwards, 1994), translated into Slovak by Sarmány-Schuller (1998). The scale, containing 14 belief statements, assessed the extent to which individuals believe that they do not fully understand the cause-and-effect relationships between underlying social events. The subjects were asked to express the degree to which they agreed with each item. A higher score indicates stronger agreement and a higher causal uncertainty. Scores ranged from 14 to 84 .

\section{Assumptions and Hypothesis}

Based on our experiences from practice and related studies, we assume a certain relationship between causal uncertainty and these selected indicators-variables (Translation literal/free, Translation - adequate/inadequate, Fluency, Translation Quality into Mother Tongue, Academic Achievements, Internships and Study Year). We try to discover the extent to which selected variables explain or affect the causal uncertainty of an individual.

A1: We assume that there is a negative correlation between causal uncertainty and participation in long-term internship abroad.

Since individuals high in causal uncertainty feel higher uncertainty in social relationships and they have a need for stereotype, they would be unlikely to expose themselves to situations such as travelling abroad or participation in the internship. The stay in a foreign country with a foreign culture, new social interactions, and a different system of study may lead to expectations increasing uncertainty beliefs and anxiety. On the other hand, individuals low in causal uncertainty would consider the internship as an opportunity to avoid stereotypes or as a challenge.

A2: We assume that there is a positive correlation between causal uncertainty and a tendency to literal translation. 
Since individuals high in causal uncertainty have higher need for stereotypes, they would prefer to follow the source text more strictly to avoid uncertainty beliefs. Literal translation represents a "safer" choice. Conversely, the individuals low in causal uncertainty would tend to avoid stereotypes and prefer free translation.

A3: We assume that there is no significant correlation between causal uncertainty of an individual and adequacy of translation, as well as between causal uncertainty and overall evaluation of the language fluency by the reader.

$\mathrm{CU}$ of an individual does not influence the ability to translate selected text segments adequately. We suggest that the ability to translate the text adequately is related more to the language competence of an individual (in both A and B languages), their analyti$\mathrm{cal}$, interpretational, and information mining and verification competence. Similarly, the ability to translate complete text adequately depends more on foreign-language competence and the ability to adequately use wording in the target language.

A4: We assume that there is no significant correlation between causal uncertainty of an individual and their performance in simultaneous interpreting.

Regarding the fact that the target text is realized in parallel with the reception of the source text, the interpreter works under time pressure. Their priority is to transfer the meaning of the text units and to provide the listener with as much information as possible. Cognitive load in the reception and production phases in the process of interpreting is so high that the interpreter's capacity to monitor their output is between low and zero. In these situations, self-correction and opting for appropriate equivalents is not possible (or limited). The tendency to avoid stereotypes and to search for new, vague stimuli is minimized.

Based on our assumptions, we articulate the following null hypothesis: "Causal uncertainty (CUS) does not relate with the following selected indicators-variables (Translation - literal/free, Translation - adequate/ inadequate, Fluency, Translation Quality into Mother Tongue, Academic Achievements, Internships and Study Year)."

\section{ANALYSES AND RESULTS}

Due to the presence of dichotomic variable (internships-mobility) we used a nonparametric correlation - Kendall's coefficient tau to choose the indicators (variables) and to determine the degree of dependency between causal uncertainty and selected indicators/variables (literal/free translation, adequate/inadequate translation, fluency, translation quality into mother tongue, academic achievements, internships and study year).

Based on the results of the non-parametric correlation, we excluded from further analysis the indicators/variables which did not correlate with the examined variable $C U S$ (Table 1), i.e. where independence or trivial dependence was identified between CUS and the corresponding indicator/variable (Foreign-Language Proficiency, Fluency, Academic Achievements and Interpreting).

The value of the multiple coefficient of correlation is approximately 0.6 (Table 2), i.e. there is a high degree of dependence between the examined variable CUS and the chosen indicators/variables (Translation - literal/ free, Translation - adequate/inadequate, Translation Quality into Mother Tongue, Internships and Study Year) and at least one 
Table 1. Non-parametric correlation between CUS and indicators (variables)

\begin{tabular}{|l|c|c|c|c|}
\hline & Valid N & Kendall Tau & Z & p-value \\
\hline CUS \& Study year & 42 & -0.17 & -1.56 & 0.115 \\
\hline CUS \& Foreign-Language Proficiency & 42 & $0.11^{\S}$ & 1.01 & 0.311 \\
\hline CUS \& Fluency & 42 & $0.04^{\S}$ & 0.35 & 0.728 \\
\hline CUS \& Translation - literal/free & 42 & -0.19 & -1.74 & 0.083 \\
\hline $\begin{array}{l}\text { CUS \& Translation - } \\
\text { adequate/inadequate }\end{array}$ & 42 & -0.14 & -1.28 & 0.202 \\
\hline CUS \& Academic Achievements & 42 & $0.04^{\S}$ & 0.36 & 0.722 \\
\hline CUS \& Interpreting & 42 & $0.09^{\S}$ & 0.82 & 0.412 \\
\hline CUS \& Internships & 42 & $-0.21^{*}$ & -1.98 & 0.048 \\
\hline CUS \& Translation into MT & 42 & 0.16 & 1.46 & 0.144 \\
\hline
\end{tabular}

Legend: ${ }^{\S}$ excluded indicators from further analysis - independence or trivial extent of dependence, $* \mathrm{p}<0.05$

Table 2. Summary of Regression analysis - Multiple correlations, ANOVA results

\begin{tabular}{|l|l|}
\hline & Value \\
\hline Multiple R & $0.614^{* *}$ \\
\hline Multiple R2 & 0.377 \\
\hline Adjusted R2 & 0.283 \\
\hline F(5,33) & 3.996 \\
\hline p-value & 0.006 \\
\hline Std. Err. of Estimate & 6.806 \\
\hline
\end{tabular}

Legend: ** $\mathrm{p}<0.01$

regression coefficient is statistically significant $(\mathrm{F}(5,33)=3.996, \mathrm{p}=0.006)$.

By regression analysis we test whether the variable CUS depends on the chosen indicators/variables. We reject the null hypothesis stating the causal uncertainty does not depend on chosen indicators/variables, in the case of Translation-literal/free at the $5 \%$ significance level and in the case of Internships at the $1 \%$ significance level, i.e. the coefficients are statistically significant, the variable CUS is related to the indicators - Translation-literal/free and Internships (Table 3).

Based on the partial/semipartial coefficient of correlation and on a standardized regression coefficient, we can determine which of the chosen indicators has the highest influence on the examined variable CUS. The variables - Internships and Translation - literal/free have the highest influence and where we identified a medium indirectly proportional dependency, coefficients are statistically significant (Table 4). In the case of Translation into MT, we identified a small directly proportional dependency and in the case of Study Year, a small indirectly proportional dependency but the coefficients are statistically insignificant. In the case of Translation-literal/free, independence or trivial dependency was identified. 
Table 3. Significance test of individual regression coefficients

\begin{tabular}{|l|c|c|c|c|c|c|}
\hline & BETA & $\begin{array}{c}\text { Std. Err. } \\
\text { of } \\
\text { BETA }\end{array}$ & B & $\begin{array}{c}\text { Std. Err. } \\
\text { of b }\end{array}$ & $\mathrm{t}(33)$ & $\mathrm{p}$-value \\
\hline Intercept & & & $54.19^{* * *}$ & 11.88 & 4.56 & 0.000 \\
\hline Study year & -0.18 & 0.15 & -1.75 & 1.42 & -1.24 & 0.225 \\
\hline $\begin{array}{l}\text { Translation- } \\
\text { literal/free }\end{array}$ & $-0.36^{*}$ & 0.15 & $-7.42^{*}$ & 3.13 & -2.37 & 0.024 \\
\hline $\begin{array}{l}\text { Translation- } \\
\text { adequate/inadequate }\end{array}$ & -0.07 & 0.15 & -2.45 & 4.95 & -0.50 & 0.623 \\
\hline Internships & $-0.45^{* *}$ & 0.15 & $-7.96^{* *}$ & 2.57 & -3.09 & 0.004 \\
\hline Translation into MT & 0.28 & 0.15 & 4.29 & 2.23 & 1.93 & 0.063 \\
\hline
\end{tabular}

Legend: $* \mathrm{p}<0.05, * * \mathrm{p}<0.01, * * * \mathrm{p}<0.001$; BETA - standardized coefficients, $\mathrm{b}$ - unstandardized coefficients

Table 4. Partial and semipartial correlations between CUS and indicators

\begin{tabular}{|l|l|l|l|l|c|}
\hline & BETA & $\begin{array}{c}\text { Partial } \\
\text { Cor. }\end{array}$ & $\begin{array}{c}\text { Semipart. } \\
\text { Cor. }\end{array}$ & $\mathrm{t}(33)$ & $\mathrm{p}$-value \\
\hline Study year & -0.18 & -0.21 & -0.17 & -1.24 & 0.225 \\
\hline Translation - literal/free & $-0.36^{*}$ & $-0.38^{*}$ & $-0.33^{*}$ & -2.37 & 0.024 \\
\hline Translation - adequate/inadequate & -0.07 & -0.09 & -0.07 & -0.50 & 0.623 \\
\hline Internships & $-0.45^{* *}$ & $-0.47^{* *}$ & $-0.43^{* *}$ & -3.09 & 0.004 \\
\hline Translation into MT & 0.28 & 0.32 & 0.27 & 1.93 & 0.063 \\
\hline
\end{tabular}

Legend: $* \mathrm{p}<0.05, * * \mathrm{p}<0.01, * * * \mathrm{p}<0.001$; BETA - standardized coefficients

\section{DISCUSSION AND CONCLUSION}

The aim of this study was to identify any potential relationships between the causal uncertainty of an individual and the selected aspects of translation.

The results of non-parametric correlation (Table 1) confirmed a statistically significant small and negative correlation between causal uncertainty and the participation in internships $(\mathrm{r}=-.21, \mathrm{p}=.048)$. As expected, the results of the research showed the existence of a negative correlation between causal uncertainty of the students and their will- ingness to participate in internships. The students who were high in causal uncertainty were less willing to participate in abroad study programs (mobility).

Causal uncertainty and free/literal translation have a statistically significant moderate and negative correlation $(\mathrm{r}=-.38$, $\mathrm{p}=.002)$, it means the assumption about a negative relationship between causal uncertainty and a tendency for literal translation was proved. The students high in causal uncertainty were less likely to use free translation within the selected text segments; conversely, they tend to use literal translation. 
Causal uncertainty and adequate/inadequate translation have a small and negative correlation $(r=-.09)$ which is not statistically significant $(\mathrm{p}=.62)$. As expected, there is no statistically significant relationship between causal uncertainty and the adequacy of the translation procedures used by the translator.

Causal uncertainty and inadequate translation have a small negative correlation $(\mathrm{r}=$ $-.09)$, statistically not significant $(\mathrm{p}=.62)$. By this, the hypothesis that there is no correlation between causal uncertainty and inadequacy of the translation procedures of an individual was proved.

The correlation between causal uncertainty and the year of study is small and negative $(\mathrm{r}=-.21)$, not statistically significant $(\mathrm{p}=$ .23).

The research has shown that the variables foreign-language competence (foreign-language proficiency), the quality of translation from recipient's point of view (fluency), GPA (academic achievements) and the quality of interpreting (interpreting) are independent variables in respect to causal uncertainty. Thus, our hypothesis that there is no relationship between causal uncertainty and overall quality of translation and interpreting from the recipient's point of view was proved (Table 1).

We initially assumed a negative correlation between causal uncertainty and the willingness to participate in internships. The statistical analysis of data has identified statistically significant moderate and negative correlation $(\mathrm{r}=-.47)$ between $C U$ and internships (Table 4), thus confirming the assumption. Individuals high in causal uncertainty were less willing to participate in internships; on the other hand, students low in causal uncertainty were more willing to participate in abroad programs. The individuals who are less certain in cause-and-effect relationships in the social world and are high in uncertainty in their social interactions, prefer stereotypes. These individuals are unlikely to expose themselves to uncertain situations (e.g., internships, stays abroad), unknown cultures and unknown social interactions. Such social events may be associated with the feeling of improbability, uncontrollability, uncertainty, uneasiness, stress, and anxiety. As these individuals can be characterized by having a high need for structure (desire for structure) and low uncertainty tolerance, they tend to avoid such situations. On the other hand, individuals low in causal uncertainty and high in stereotype avoidance would consider the internship as a challenge, and an interesting opportunity to obtain new stimuli in social interactions. As the variable internship in comparison with the other discussed variables has primarily social and interpersonal characteristics, its relationship to casual uncertainty is the most significant one (Table 3 ).

We also assumed that there is a positive correlation between causal uncertainty and a tendency for literal translation. The analysis has shown statistically significant moderate and negative correlations between the variables. Individuals high in causal uncertainty tend to use literal translation of the selected text segments more often. As these individuals prefer stereotypes and have a lower uncertainty tolerance, we assumed that the students would tend to use literal translation to avoid uncertainty and uncontrollability of the situation. For them, literal translation would be considered a kind of "safer" option with consequences that can be easily predicted. The relationships between the author of the source text and the translator 
as his/her first reader, and between the translator as the expedient of the target text and the reader as the recipient, can be considered as indirect social interactions. Within the analysis and interpretation of the source text and thus the intention of the author, literal translation seems to be an easier translation option avoiding uncontrollability and uncertainty of the reader's reaction. The CU model suggests (Weary et al., 2010) that a causally uncertain person will attempt to regain causal understanding by choosing the action plan with the greatest perceived expectancy of success. For the translator, literal translation seems to be the decision subjectively connected with a lower risk of potential misinterpretation, not transferring the author's intention. Conversely, individuals low in causal uncertainty and high in stereotype avoidance would use free translation more often. They would probably feel higher certainty in a cause-and-effect understanding of the author's intention and feel lower concern about possible misinterpretation and an unpredicted reaction of the recipient.

We assumed that there was no significant correlation between causal uncertainty of an individual and his/her adequate translation. As expected, the hypothesis was confirmed. The level of causal uncertainty of an individual does not affect his/her ability to use adequate translation within selected text segments. The mentioned ability is likely associated with language competence (in both source and target language), interpretation abilities (ability to analyze and interpret the text), and with information mining and verifying abilities. The study has also shown that tendency to use particular translation procedures is not related to adequacy/ inadequacy of such translation. Tendency to free/literal translation does not indicate adequacy/inadequacy of the translation procedures. Adequacy is primarily given by the context, language and cultural conventions, text type and genre, generally by microtext and macrotext. A good translator is expected to vary the translation strategies and procedures so that the target text transfers the intention of the author.

In terms of the overall evaluation of translation and interpreting quality we assumed that there is no significant relationship between causal uncertainty and overall evaluation of the translation by the reader (fluency) and no significant relationship between causal uncertainty of an individual and his/ her performance in simultaneous interpreting (interpreting into the mother tongue).

The ability to perform a high-quality translation, which would be considered by the reader as fluent, depends firstly on foreignlanguage competence, precise wording in target language (A language in our study), followed by intercultural, interpretation, or information mining competence. In partial text segments, the reader may identify it as a rather literal translation or language interference. Regarding the level of interference, literal translation of selected text segments may have only a slight influence, as the quality of the target text from the recipient's point of view is affected by many external (objective) and internal (subjective) variables, e.g. information-saturated text, topic, text genre, translator's experience, deadline, etc.

There are also many subjective and objective factors influencing the quality of an interpreter's performance, e.g. the length and difficulty of the text, technical conditions, speech rate of the speaker, the interpreter's experience. As in simultaneous interpreting, production of the target text is realized in parallel with the reception of the source text 
(in CI in parallel with the notation), so the interpreter is always under time pressure. His/ her priority is to convey (interpret) the basic meaning of the speech and to provide the listener with as much information as possible. Both reception and production phases require so much time and cognitive capacity that the interpreter's monitoring of their output is low or zero, and immediate evaluation, self-correction and evaluation of the interpreter's decisions is, in most cases, impossible. The tendency to avoid stereotypes and to search for new, vague stimuli is minimized. By comparison with translation, in evaluating the interpreter's performance overall, literacy of transfer procedures is more acceptable. Regarding the specifics of interpreting, the listener seems to tolerate more formal errors in the source text. It is likely, and it may be the objective of our further research, that causal uncertainty would play a more important role in consecutive interpreting, namely in interpreting notation where following the source text more strictly may influence the quality of the notation, thus the overall quality of the target text.

Considering the fact that the study was conducted on a relatively small sample ( $\mathrm{n}=$ 42 ), we can indicate only a tendency, however, the results cannot be generalized. The validity of the study needs to be verified on larger sample size (Hvorecký et al., 2010) within further studies.

Received February 28, 2014

\section{REFERENCES}

BERGER, C.R., BRADAC, J.J., 1982, Language and social knowledge: Uncertainty in interpersonal relations. London: Edward Arnold.

ĎURAČKOVÁ, B., ČECHOVÁ, L., 2012 , Translating idioms: An interdisciplinary issue versus fun. Teaching Translation and Interpreting
Skills in the 21st Century, Vol. 1 (pp. 125-135). Olomouc: UP.

EDWARDS, J.A., 2003, The interactive effects of processing preference and motivation on information processing: Causal uncertainty and the MBTI in a persuasion context. Journal of Research in Personality, 37, 89-99.

GILE, D., 1993, Using the effort models of conference interpretation in the classroom. Folia Translatologica (pp. 135-143). Praha: Univerzita Karlova.

GILE, D., 1995, Basic concepts and models for interpreter and translator training. Amsterdam/ Philadelphia: John Benjamins.

GROMOVÁ, E., JANECOVÁ, E., 2013, Audiovisual translation - dubbing and subtitling in Slovakia, World Literature Studies, 5, 4, 61-71.

HODÁKOVÁ, S., 2009, Pamät' v simultánnom a konzekutívnom tlmočení (PhD. Thesis) Nitra

HVORECKÝ, J., DRLÍK, M., MUNK, M., 2010 , The effect of visual query languages on the improvement of information retrieval skills. Procedia-Social and Behavioral Sciences, 2, 2, 717 723.

KURZ, I., 1994, A look into the "black box". In: M. Snell-Hornby, F. Pöchhacker, K. Kaindl (Eds.), Translation Studies: An Interdiscipline: Selected papers from the Translation Studies Congress, Vienna.

KURZ, I., 2002, Physiological stress responses during media and conference interpreting. In: G. Garzone, M. Viezzi (Eds.), Interpreting in the 21st Century: Challenges and opportunities (pp. 195202).

MÜGLOVÁ, D., 2009, Komunikácia, tlmočenia, preklad alebo prečo spadla Babylonská veža?, Nitra: Enigma.

NEUBERG, S.L., NEWSOM, J.T., 1993, Personal need for structure: Individual differences in the desire for simple structure. Journal of Personality and Social Psychology, 65, 113-131.

NIDA, E.A., TABER, CH.R., 1969, The theory and practice of translation. Leiden: E.J. Brill.

PÖCHHACKER, F., 1999, The importance of nonverbal communication. Interpreting. International Journal of Research and Practice in Interpreting, 2.

SARMÁNY SCHULLER, I., 1999, Neistotaistota (Prípad kauzálnej neistoty). In: M. Bratská, E. Naništová, I. Sarmány Schuller (Eds.), Reflexie súčasnej psychológie na Slovensku. Trenčín, (pp. 13-19). Bratislava: Stimul. 
SARMÁNY-SCHULLER, I., 2001, Potreba štruktúry a schopnost' vytvárania štruktúry ako osobnostné konštrukty. In: I. Sarmány-Schuller (Eds.), Zborník Psychológia pre bezpečný svet, Psychologické dni, Trenčín, Sept. 10-12. Bratislava: Stimul.

SHERBLOM, J., VAN RHEENEN, D.D., 1984, Spoken language indices of uncertainty. Human Communication Research, 11, 2, 221-230.

ŠTEFČÍK, J., 2012, Traduction a 1'aidede la traduction assistée par ordinateur. XLinguae: European Scientific Language Journal, 5, 4.

WEARY, G., TOBIN, S.J., EDWARDS, J.A., 2010, The causal uncertainty model revisited. In: R.M. Arkin, K.C. Oleson, P.J. Carroll (Eds.), Handbook of the uncertain self (pp. 78-100). New York, NY: Psychology Press.

WEARY, G., 1994, Individual differences in casual uncertainty. Journal of Personality and Social Psychology, 67, 2, 308-318.

WEARY, G., TOBIN, S.J., 1994, Chronic and temporality activated casual uncertainty beliefs and stereotype usage. Journal of Personality and Social Psychology, 67, 2, 206-219.

WEARY, G., VAUGHN, L.A., STEWART, B.D., EDWARDS, J.A., 2006, Adjusting for the correspondence bias: Effects of causal uncertainty, cognitive busyness, and causal strength of situational information. Journal of Experimental Social Psychology, 42, 87-94.

\title{
KAUZÁLNA NEISTOTA
}

\author{
D. M u n k ová, S. H o d á k ová, K. W e 1 n i t z o vá
}

Súhrn: Štúdia sa zameriava na kauzálnu neistotu (CU) ako osobnostný sebakonštrukt v sociálnom kontexte a jej vplyv na translačnú činnost' jedinca. Skúma vzt'ah kauzálnej neistoty jedinca $\mathrm{k}$ vybraným aspektom prekladatel'skej činnosti (vol'nost'/doslovnost' prekladu, adekvátnost') neadekvátnost' prekladu, prirodzenost' jazyka prekladu a kvalita tlmočenia do materinského jazyka). Kauzálnu neistotu jednotlivcov sme zist'ovali použitím škály kauzálnej neistoty (CUS) a na získané dáta sme aplikovali regresnú analýzu. Výsledky ukázali štatisticky významný vplyv kauzálnej neistoty jedinca na jeho ochotu zúčastnit’ sa dlhodobého pobytu v zahraničí (stáž) ako aj na jeho tendenciu k vernému prekladu (doslovný/volný preklad). 